\title{
Diagnostic sign of intra uterine extra amniotic adhesions with 4D ultrasonography: Sheet on string
}

\section{Intra uterin ekstra amniyotik adhezyonlarin 4D ultrasonografi ile tanısı: İpteki çarşaf}

\author{
(1) Eray Çalışkan', (1) Rukiye Ada Bender², (1) Reyhan Aslancan³ \\ ${ }_{1}$ Bahçeşehir University Faculty of Medicine, Department of Obstetrics and Gynecology, İstanbul, Turkey \\ 2İstinye University Faculty of Health Sciences, Clinic of Obstetrics and Gynecology, İstanbul, Turkey \\ ${ }^{3}$ Bahçeşehir University Faculty of Medicine, İstanbul, Turkey
}

\section{Keywords}

Extra amniotic adhesions, 4D ultrasonography, sheet on string

\author{
Anahtar Kelimeler \\ Ekstra amniyotik adhezyonlar, 4D ultrasonografi, ipteki çarşaf
}

\section{Dear editor;}

Intra uterine adhesions seen in pregnancy, which were defined in 1894 by Joseph G. Asherman, are divided into two groups as intra amniotic and extra amniotic adhesions. Intra uterine intra amniotic adhesions, which are also known as intra amniotic bands, are easily detectable in first and second trimester ultrasonographic examinations; therefore, close follow-up could provide an appropriate approach. Also intrauterine extra amniotic adhesions are a causative factor of infertility, early pregnancy loss, preterm delivery, cesarean section due to malpresentation, placental invasion abnormalities, and intra uterine fetal death ${ }^{(1,2)}$. There are no ultrasonographic diagnostic signs for intrauterine extra-amniotic adhesions in the literature, and the presumption of negative pregnancy outcomes and following up these patients is difficult for obstetricians. The aim of this study was to provide a handy method to distinguish intrauterine extra- amniotic adhesions for pregnancy outcomes and postpartum follow-up. Based on second trimester detailed ultrasonography outcomes, twenty-four patients were identified as having intrauterine extra amniotic adhesions through 4D ultrasonographic investigations. Sixteen patients had cesarean deliveries; the indications were previous cesarean section for ten, presentation abnormality for four, and placentation abnormality for two of the pregnant women. The intrauterine extra amniotic adhesions were verified during cesarean operations. Eight of the pregnant women had vaginal deliveries and six months after the delivery, adhesions were verified via hysteroscopic imaging. The locations of the adhesions were observed as following: fifteen of the women who had cesarean section had isthmic adhesions (93.75\%), and one had cornual adhesion (6.25\%). All eight women who had vaginal deliveries had adhesions in the uterine cornu (100\%). In conclusion, intrauterine extra-amniotic adhesions can be identified by a specific ultrasonographic appearance known as "sheet on string," because it looks like a sheet spread out on a string (Figure 1, 2). Intra uterine adhesions that have not been identified in the preconception period but are important for pregnancy follow-up can be determined using 4D ultrasonography during anomaly screening with the advantage of amniotic fluid's image quality increasing effect.

Address for Correspondence/Yazışma Adresi: Reyhan Aslancan, MD,

Bahçeșehir University Faculty of Medicine, İstanbul, Turkey

Phone: +90 5389530231 E-mail: reyhanaslancan@gmail.com ORCID ID: orcid.org/0000-0001-5092-3151

Received/Geliș Tarihi: 18.03.2018 Accepted/Kabul Tarihi: 20.03.2018

${ }^{\oplus}$ Copyright 2018 by Turkish Society of Obstetrics and Gynecology

Turkish Journal of Obstetrics and Gynecology published by Galenos Publishing House 


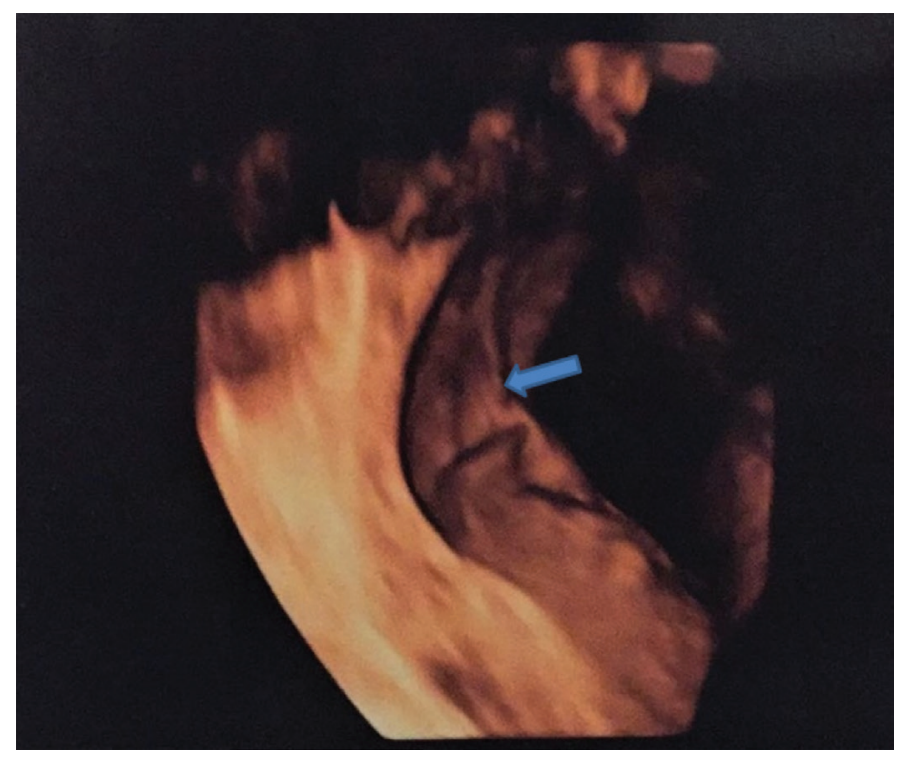

Figure 1. Intrauterine extra-amniotic adhesion demonstrated using 4D ultrasonography; "sheet on a string" appearance

\section{Ethics}

Peer-review: External and internal peer-reviewed.

\section{Authorship Contributions}

Surgical and Medical Practices: E.Ç., Concept: E.Ç., Design: E.Ç., Data Collection or Processing: R.A.B., R.A., Analysis or Interpretation: R.A.B., R.A., Literature Search: R.A.B., R.A., Writing: R.A.

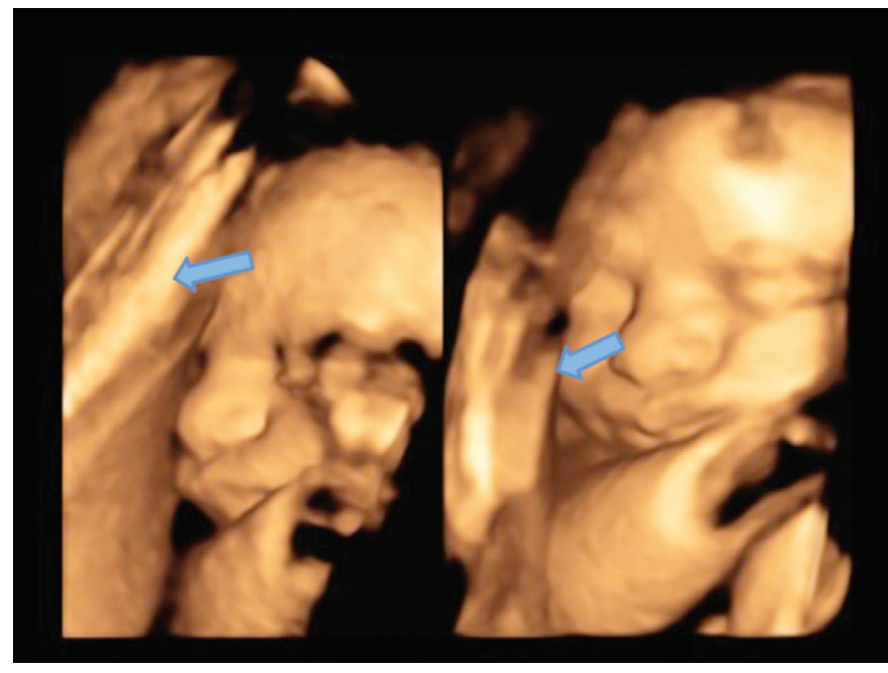

Figure 2. Intrauterine extra-amniotic adhesion demonstrated using 4D ultrasonography; "sheet on a string" appearance

Conflict of Interest: No conflict of interest was declared by the authors.

Financial Disclosure: The authors declared that this study received no financial support.

\section{References}

1. Fritsch H. Ein Fall Von Volligen Schwund der Gerbarmutterhole nach Auskratzung. Zentralbl Gumsrl 1894;18:1337.

2. Schoot BC. Extra Amniotic Band Syndrome" Uterine Synechiae and Development of Early Pregnancy. Journal of Minimally Invasive Gynecology 2009;16:32. 